\section{Impact of observed climate change on the classification of agroclimatic zones in India}

\author{
N. Chattopadhyay ${ }^{1, *}$, A. K. Sahai ${ }^{1}$, \\ P. Guhathakurta ${ }^{1}$, S. Dutta ${ }^{1}$, A. K. Srivastava ${ }^{1}$, \\ S. D. Attri ${ }^{2}$, R. Balasubramanian ${ }^{1}$, K. Malathi ${ }^{1}$ \\ and Swati Chandras ${ }^{1}$ \\ ${ }^{1}$ India Meteorological Department, Shivajinagar, Pune 411005 , India
${ }^{2}$ India Meteorological Department, New Delhi 110 003, India
}

The classification of agroclimatic zones in India was made in the 1990 s for identifying priorities and developing strategies for location-specific and need-based research as well as overall agricultural development in the country. Long-term climatic parameters, particularly temperature and rainfall along with soil and crop information were used for the classification of agroclimatic zones. It has been documented with a fair degree of accuracy that overall climate is changing, particularly with respect to temperature over the Indian region. Thus it is anticipated that in the recent past, climate change may be reflected in the agroclimatic zones as well and ultimately affect the criteria of their classification based on climatic parameters. The objective of the present study is to examine the trends and spatial/temporal variability of temperature, rainfall, rainy days, and heavy rainfall in different agroclimatic zones of the country, which may help in better understanding of the further initiatives on reclassification of agroclimatic zones, if required. Using various long-term gridded data from 1985 and instrumental datasets starting from 1951 to 1980 , studies have been made to observe changes in different components of the climatic variables, i.e. temperature and rainfall. It has been observed that there are significant changes in temperature and rainfall, both temporally and spatially, across India and there is a definite shift in temperature and rainfall patterns in the recent past compared to 1951-1980. It has also been inferred that there is a need to reconsider the classification of agroclimatic zones in India under the scenario of observed climate changes in the country.

Keywords: Agroclimatic zones, classification, climatic parameters, climate change.

WEATHER and climate are the key factors in agricultural production, right from the field preparation to marketing. The success or failure in farming is closely associated with the prevailing weather conditions. Hence it is possible to optimize farm production by adjusting the cropping patterns and agronomic practices to suit the climate of an area, if fairly good knowledge about the agroclimatic

*For correspondence. (e-mail: nabansu.nc@gmail.com) regions (based on physiography, soils, geological formation, climate, cropping patterns and irrigation and mineral resources for broad agricultural planning and developing future strategies) of a country is readily available. The Indian subcontinent falls under a wide variety of agroclimatic zones. The zones are identified based on a number of climatic parameters, including soil and crop information. Such an approach provides the desirable framework of sustainable use of land, water and vegetation. An action programme on agricultural research and agroclimatic zones of India was initiated by the Indian Council of Agricultural Research (ICAR), New Delhi in 1979 by launching the National Agricultural Research Project (NARP) ${ }^{1}$. Under NARP, the concept of zoning was mainly based on ecological land classification, recognizing various components like soils, climate, topography, vegetation, crops, etc. Considering the above variables, homogenous zones were identified as continuous areas within the state boundary with each zone covering 2-4 districts and $42-45$ sq. $\mathrm{km}$ area. In the 1990s, ICAR had divided the whole country into 127 agroclimatic regions ${ }^{1}$.

From ancient times, Indian agriculture is based on monsoon rainfall. There is a positive relationship between agriculture and climate change. The increasing temperature is also affecting Indian agriculture by reducing the productivity of rabi crops like wheat and mustard. At the national level, an increase of $0.4^{\circ} \mathrm{C}$ has been observed in surface air temperature during the past century.

Though climate change studies have been made at the national and state level, not many studies have been carried out at the agroclimatic zone level where specific crops are grown according to the characteristics of the agroclimatic regions. Thus any change in climatic parameters, particularly temperature and rainfall, in the agroclimatic zones will have a significant bearing on the existing agroclimatic classification as well as crop production. The present study reveals interesting observations in the recent past on the changes in climatic variables in the agroclimatic zones of India. Using longterm gridded data starting from 1985 and instrumental data from 1951 to 1980 , the observed changes in various components in the above-mentioned climate scale are discussed. To the best of our knowledge, no such comprehensive, and relatively long-term assessment of climate change has been undertaken earlier for agroclimatic zones in the country.

Monthly and seasonal temperature datasets and rainfall for the different agroclimatic zones (for operational purpose, the agroclimatic zones have been divided into cluster of districts) for the period 1986-2015 with grid size of $0.25^{\circ} \times 0.25^{\circ}$ for rainfall and $0.5^{\circ} \times 0.5^{\circ}$ for temperature were used for the study.

A trend in the temperature (maximum and minimum) and rainfall series over a period of 31 (1985-2015) was examined at agroclimatic zonal levels. Significance was 


\section{RESEARCH COMMUNICATIONS}
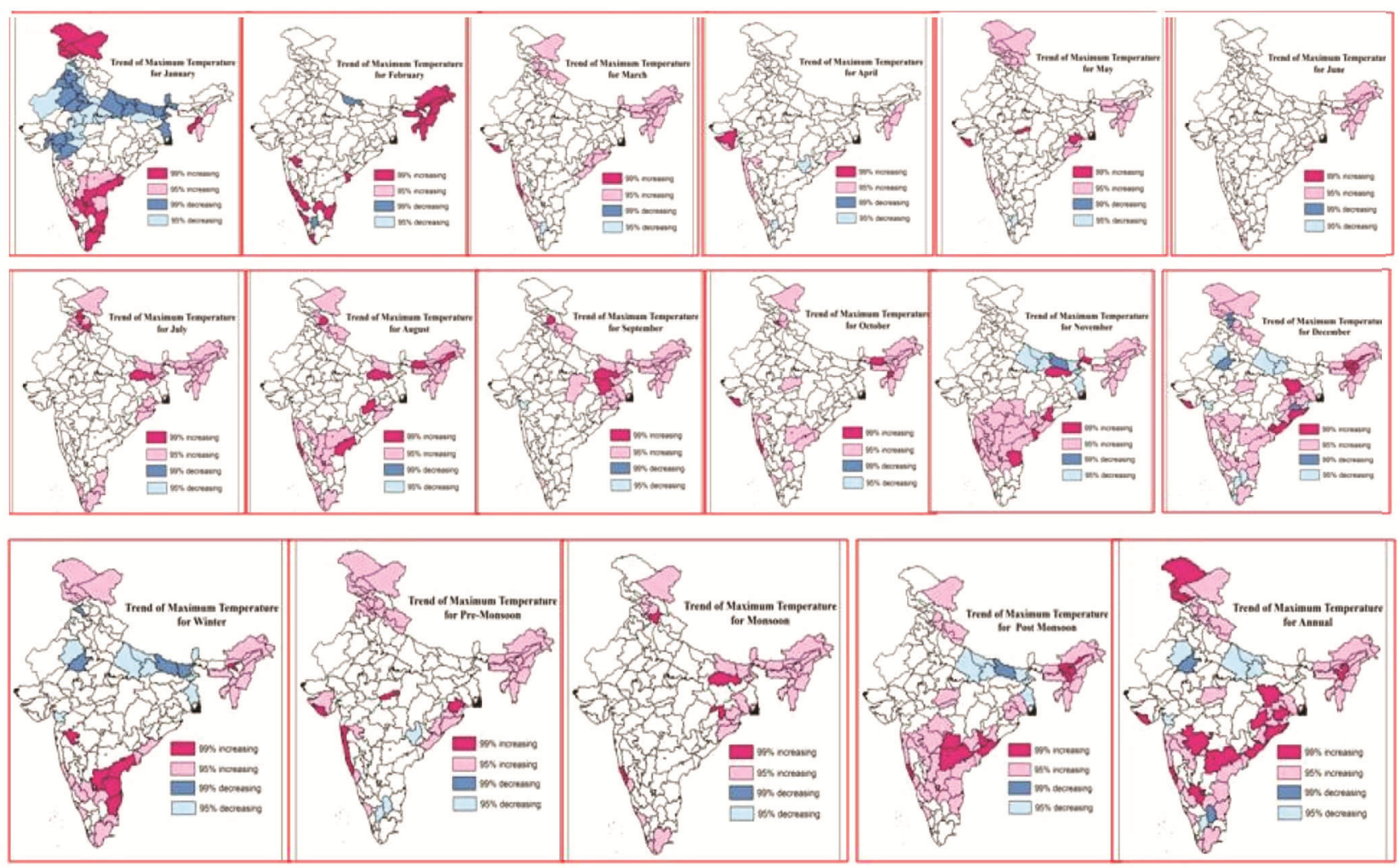

Figure 1. Trends of maximum temperature in various months and seasons in India.

at $95 \%$ and $99 \%$ levels for temperature and at $90 \%, 95 \%$ and $99 \%$ levels for rainfall due to spatial variability.

From daily rainfall data, heavy rainfall events were counted using the criterion of India Meteorological Department (IMD), i.e. rainfall amount $\geq 64.5 \mathrm{~mm}$ in $24 \mathrm{~h}$. The number of heavy rainfall events was counted and frequency is calculated by the number of stations reporting heavy rainfall events per total number of stations in the zone and the trend for each month.

The number of rainy days was determined using the following criterion: if 'rainfall is $\geq 2.5 \mathrm{~mm}$, then it is considered as a rainy day. The number of rainy days was counted and frequency is calculated by the number of rainy day per total number of stations in the zone.

Analysis of trends in maximum temperature during 1985-2015 indicates that most of the zones in the states of North East India exhibit significant (either at $99 \%$ or at $95 \%$ confidence level) warming on annual and seasonal scale range $0.04^{\circ}-0.05^{\circ} \mathrm{C} /$ year (Figure 1). For monthly scale also most of the zones in NE India, exhibit significant warming, except in January and April, ranging from $0.02^{\circ}$ to $0.08^{\circ} \mathrm{C} /$ year. During the transitional month (March) of the season from winter to pre-monsoon, maximum warming is noticed in the region. In the southern region, similar increasing trends in maximum temperature ranging from $0.01^{\circ}$ to $0.03^{\circ} \mathrm{C} /$ year have been observed over most of the zones on the annual scale, except agro- climatic zones of Tamil Nadu and the same pattern is observed in most of the months ranging from $0.02^{\circ}$ to $0.06^{\circ} \mathrm{C} /$ year, except during March-June and SeptemberOctober when there is no significant change. However, the western and northwestern zones in Tamil Nadu exhibit cooling trends ranging from $-0.01^{\circ}$ to $-0.03^{\circ} \mathrm{C} /$ year in February-May during pre-monsoon and also on the annual scale. In the zones of central and western India, significant decreasing trend is observed mostly in Gujarat, excluding Saurashtra and Madhya Pradesh in January, the peak winter month, ranging from $-0.04^{\circ}$ to $-0.06^{\circ} \mathrm{C}$ and $-0.05^{\circ}$ to $-0.07^{\circ} \mathrm{C}$ year respectively. However, Konkan and central Maharashtra, excluding Vidarbha show a warming trend in the post-monsoon months ranging from $0.02^{\circ}$ to $0.09^{\circ} \mathrm{C} /$ year. No significant changes are observed in all the months in Chhattisgarh and Madhya Pradesh. Most of the agroclimatic zones of Jammu and Kashmir show significant increasing trend on the annual scale ranging from $0.02^{\circ}$ to $0.04^{\circ} \mathrm{C} /$ year, with maximum trend observed in January, i.e. $-0.07^{\circ}$ to $-0.12^{\circ} \mathrm{C} /$ year. During the peak winter month of January, except Uttarakhand and Himachal Pradesh all the other states show cooling effect ranging from $-0.05^{\circ}$ to $-0.08^{\circ} \mathrm{C} /$ year in Haryana, $-0.05^{\circ}$ to $-0.08^{\circ} \mathrm{C} /$ year in Punjab, $-0.04^{\circ}$ to $-0.07^{\circ} \mathrm{C} /$ year in Rajasthan and $-0.07^{\circ}$ to $-0.14^{\circ} \mathrm{C} /$ year in Uttar Pradesh. Rest of the months, not much significant warming/ cooling effect is noticed. The zones in the states of 


\section{RESEARCH COMMUNICATIONS}
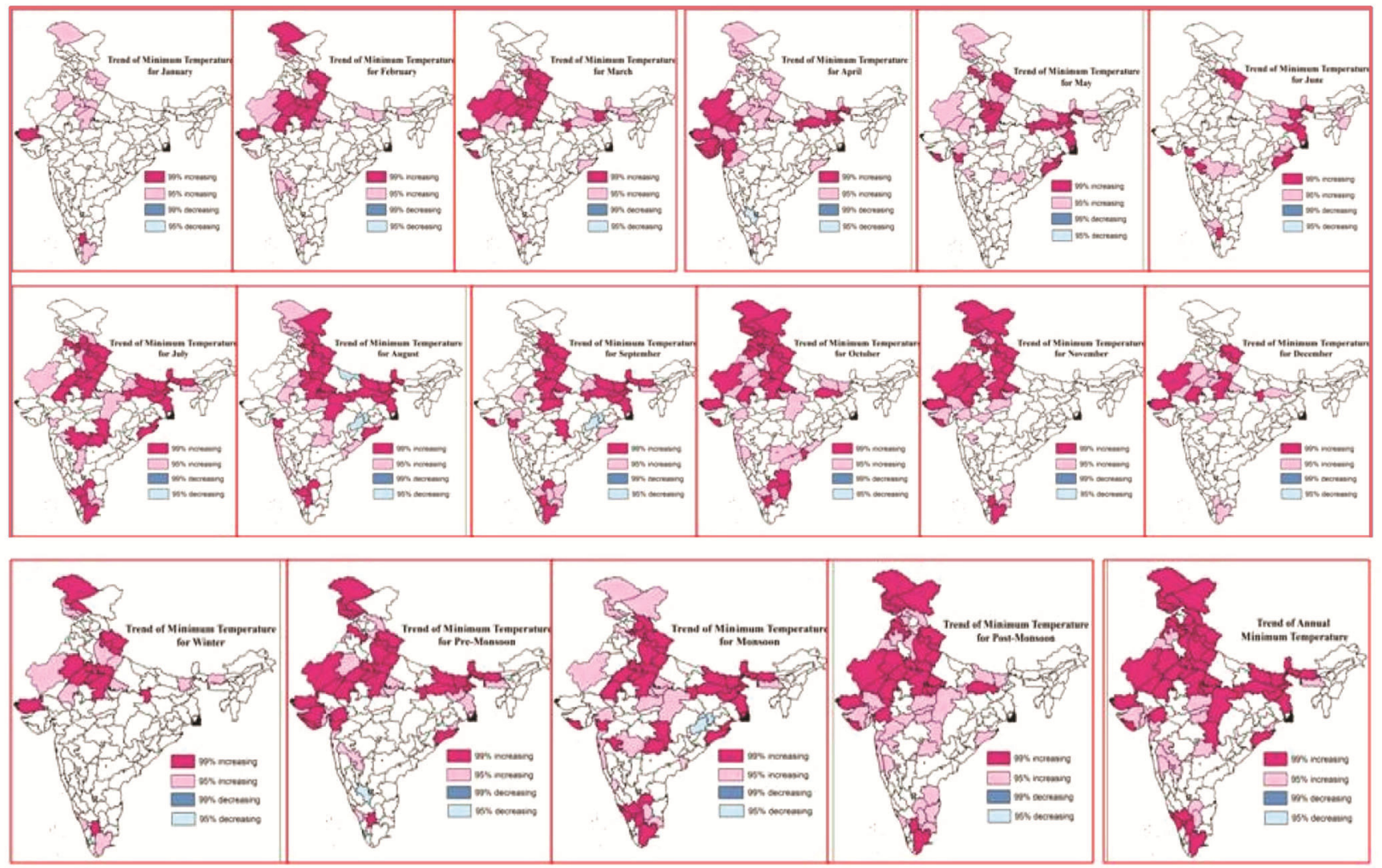

Figure 2. Trends of minimum temperature in various months and seasons in India.

eastern India do not show significant changes in maximum temperature. However, during January coastal and adjoining coastal areas of West Bengal show a cooling trend ranging from $-0.05^{\circ}$ to $-0.08^{\circ} \mathrm{C} /$ year, while in $\mathrm{Bi}$ har and Jharkhand it is $-0.05^{\circ}$ to $-0.09^{\circ} \mathrm{C} /$ year. Most of the zones in Odisha do not exhibit any significant change in maximum temperature during the period of study, either at $99 \%$ or at $95 \%$ level.

Analysis of minimum temperature trends in the country indicates no significant changes in various regions, except significant warming trends observed over most of the states during the monsoon season in various temporal scales (Figure 2). Almost all the zones in the states and the central region, the southern states (excluding Karnataka), Maharashtra, West Bengal, Haryana, Rajasthan and Uttarakhand exhibit no significant changes in the months and seasons. The eastern and southern dry zones of Karnataka exhibit an increasing trend in all monsoon months ranging from $0.02^{\circ}$ to $0.03^{\circ} \mathrm{C} /$ year, with annual range from $0.014^{\circ}$ to $0.017^{\circ} \mathrm{C} /$ year. The same trend of increase in minimum temperature is noticed in the monsoon months in Bihar and adjoining Jharkhand, in the range $0.03^{\circ}-0.06^{\circ} \mathrm{C} /$ year. Central Odisha region exhibits a trend of $0.01^{\circ}$ to $0.03^{\circ} \mathrm{C} /$ year. In the western part, most of the zones in Gujarat region exhibited warming trend annually and in pre- and post-monsoon, ranging from $0.01^{\circ}$ to $0.05^{\circ} \mathrm{C} /$ year, but the same is not observed during individual months. Zones in Himachal Pradesh exhibit warming trend from July to November in the range $0.03^{\circ}-0.04^{\circ} \mathrm{C} /$ year at various temporal scales with maximum trend noticed in the monsoon season with $0.05^{\circ} \mathrm{C} /$ year. Agroclimatic zones in Jammu and Kashmir exhibit increasing trend during post-monsoon months with maximum trend observed in the transitional month of October $\left(0.09^{\circ} \mathrm{C} /\right.$ year $)$. The western part of Uttar Pradesh exhibits warming trend from March to September, i.e. pre-monsoon to monsoon ranging from $0.03^{\circ}$ to $0.07^{\circ} \mathrm{C} /$ year with highest in July $0.05-0.07^{\circ} \mathrm{C} /$ year.

These findings are also supported by earlier studies carried out using long-period data over the Indian region, though the extent of warming differs in the present study compared to the earlier studies. Kothawale et al. ${ }^{2}$, examined the temperature data during 1901-2007 and concluded that there was a significant rise in all-India mean, maximum and minimum temperatures, and that the rate of the warming was more in recent years. According to Srivastava et $a l .^{3}$ annual mean and maximum temperatures for the country as a whole have increased significantly by around $0.6^{\circ} \mathrm{C}$ and $1.0^{\circ} \mathrm{C}$ per 100 years respectively, during 1901-2010. They also mentioned that most of the rise in maximum and minimum temperatures during the recent 30 years is more prominent over 
RESEARCH COMMUNICATIONS
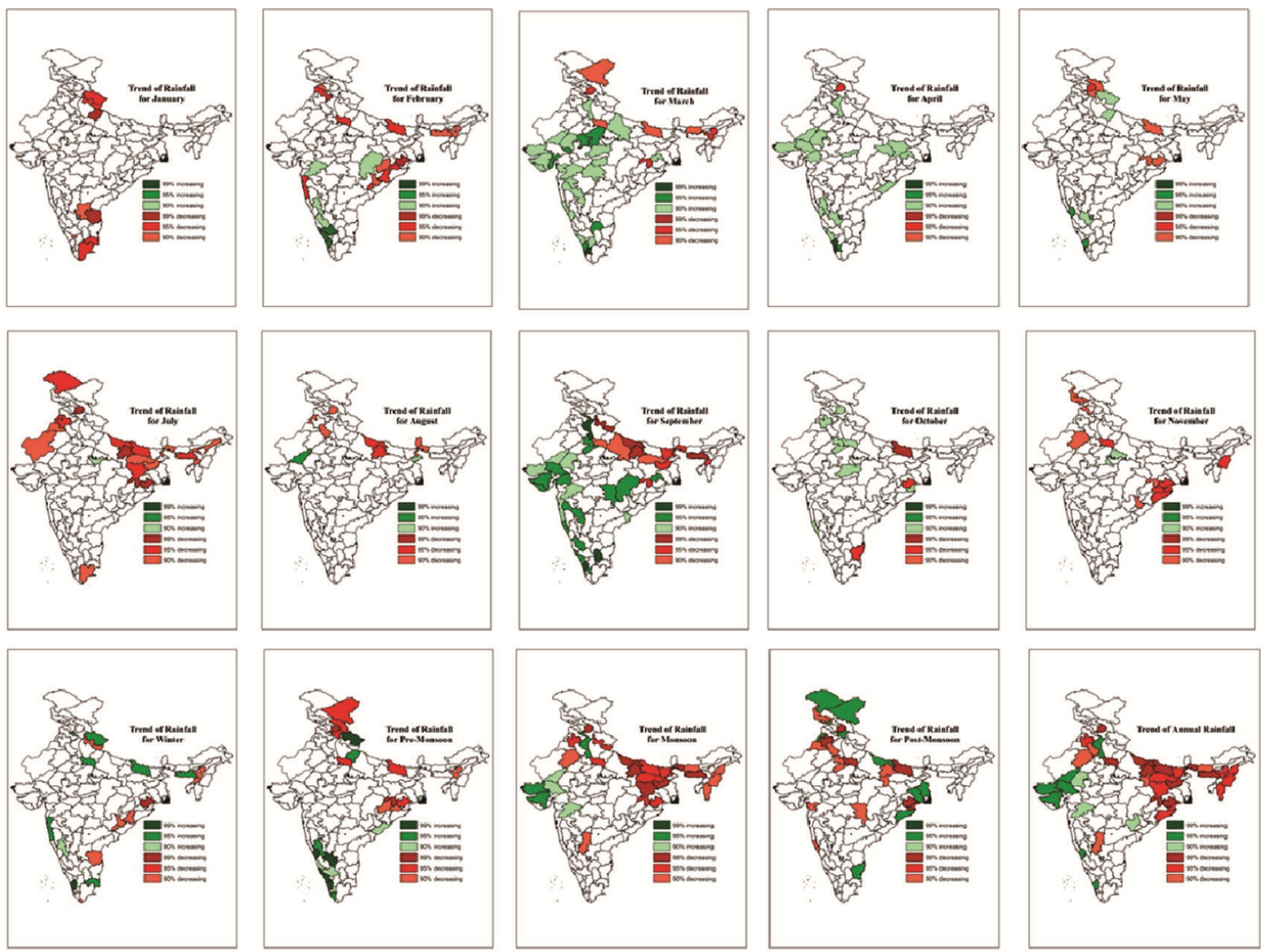
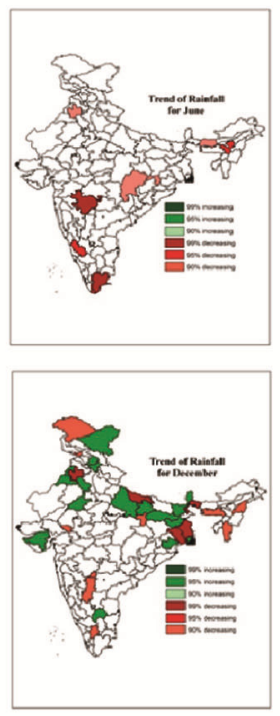

Figure 3. Trends of rainfall in various months and seasons in India.

the northern, central, eastern and northeastern parts of the country and that peninsular India witnessed the least warming during the recent 30 -year period.

There is great regional and temporal variation in the distribution of rainfall (Figure 3 ). Over $80 \%$ of the annual rainfall is confined to the four rainy months from June to September. In winter, the northern part of the country and during pre-monsoon season, West Bengal and adjoining states and also NE India receive rainfall due to thunderstorm activities. For Tamil Nadu, post-monsoon is the principal rainy season accounting for about $48 \%$ of the annual rainfall. Weakening of the monsoon circulation over India has been documented in recent studies ${ }^{4,5}$. It is found that rainfall activity during monsoon exhibits decreasing trend (99\%, 95\% and 90\% level) in foothills of the Himalaya up to Jammu and Kashmir and NE India, except Arunachal Pradesh and Gangetic West Bengal. However, compared to the eastern part of the country, particularly Gujarat $(0.01 \mathrm{~mm} /$ year $)$ and adjoining Rajasthan (transitional plain zone of inland drainage) exhibit increasing trend in the monsoon season. In the NE region, annually decreasing trend has been observed in Nagaland, Manipur, Meghalaya, Mizoram and Tripura. In Bihar, all the three zones exhibit decreasing trend annually $(-0.02$ to $-0.01 \mathrm{~mm} /$ year), but only the north west alluvial plain zone exhibits decreasing trend in monthly analysis, whereas it exhibits a decreasing trend in rainfall during monsoon season $(-0.01 \mathrm{~mm} /$ year $)$. The hill zone of West Bengal shows a decreasing trend during the monsoon months of July-September $(-0.03 \mathrm{~mm} /$ year $)$.

Winter season shows decreasing rainfall activity in the hilly areas of India, i.e. Uttarakhand, Bihar (northwest alluvial plain zone) and Meghalaya and in some agroclimatic zones in the rest of the country. It is also observed that the northern part of India does not show any significant trend of increase/decrease during these months during heavy rainfall and rainy days, except Arunachal Pradesh, which exhibits a decreasing trend. The same pattern of decreasing trend of heavy rainfall and rainy days has been observed in these regions on a monthly scale ( -0.37 to -0.07 days/year).

Post-monsoon season rainfall is the principal rainy season for the southern states. Rainfall in post-monsoon season exhibits decreasing trend in Northern Tamil Nadu and some agroclimatic zones of Odisha and adjoining West Bengal, eastern Uttar Pradesh, Punjab, Haryana and the hilly regions of Jammu and Kashmir. Frequency of heavy rainfall events during December exhibits a decreasing trend from Gujarat and adjoining Rajasthan, to West Bengal and Sikkim. Trends of rainy days and monthly rainfall exhibit similar pattern $(-0.75$ to 0.2 days/year).

Pre-monsoon rainfall mostly affects central, eastern and NE India. Pre-monsoon rainfall activity shows 


\section{RESEARCH COMMUNICATIONS}
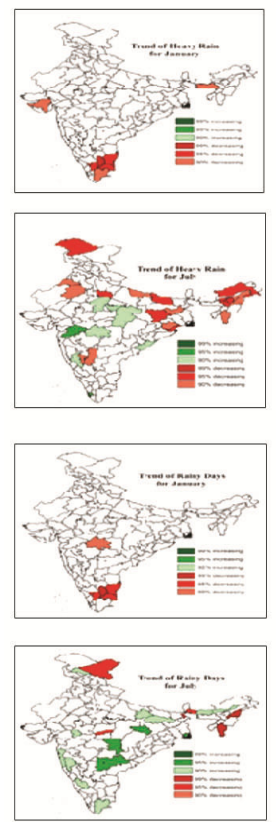
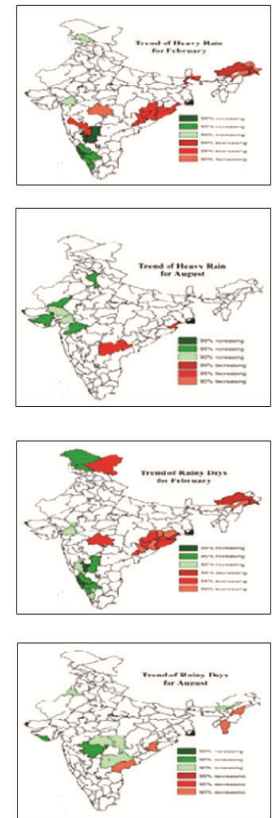
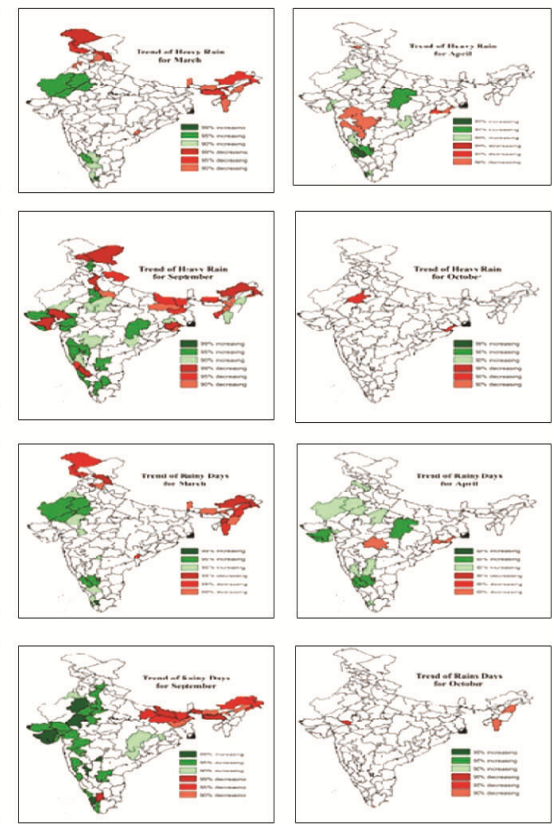
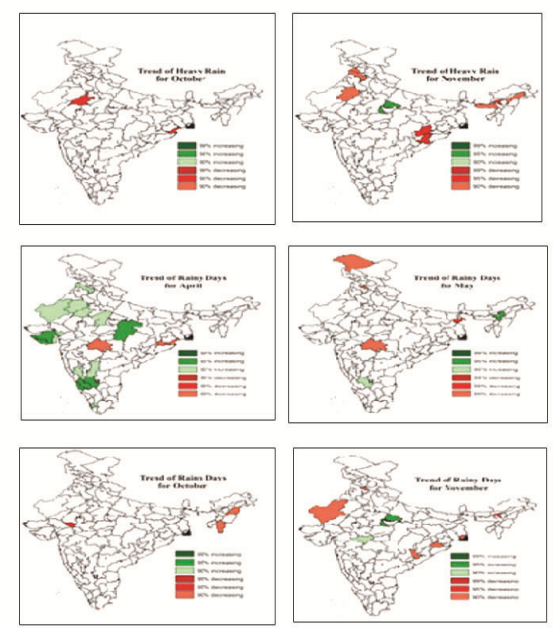
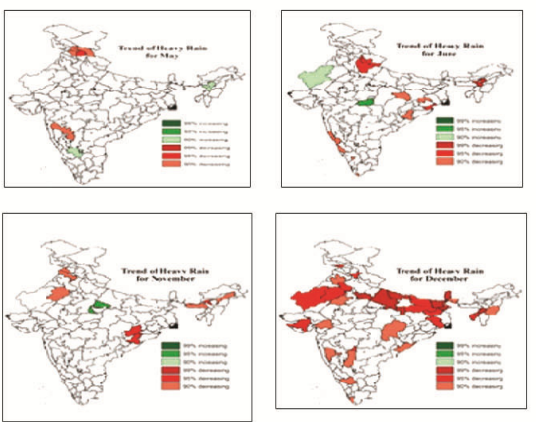
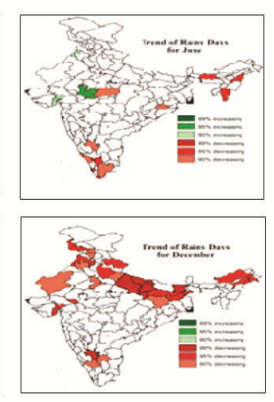

Figure 4. Trends of heavy rain and rainy days in various months in India.

decreasing trend in some agroclimatic zones of Odisha, Himachal Pradesh, and the cold arid zone of Jammu and Kashmir, but increasing rainfall activity has been noticed over the west coast from Goa to Kerala. Heavy rainfall events are observed to increase over Rajasthan in March, but decrease over the states of NE India. But results exhibit significant positive trend of increased rainfall activity in the transition month (winter to pre-monsoon) over many agroclimatic zones across the country (0.01-3.47 mm/ year). Heavy rainfall and rainy day events during the past 31 years have decreased over Maharashtra during April; on the contrary, they have increased over northern Karnataka and eastern Uttar Pradesh during the same month.

The interannual variability of monsoon rainfall has been rigorously examined by several researchers in the past $^{6-8}$ to assess long-term changes in global monsoon precipitation.

Primarily heavy rainfall (Figure 4) events occur during pre-monsoon (March-May), southwest monsoon (JuneSeptember) and northeast monsoon (October-December). NE India receives significant amount of rainfall during the pre-monsoon season of March-May (MAM). While rest of the country receives about $8 \%$ of annual rainfall during this season, NE India receives more than $25 \%$ of its annual rainfall during MAM. It has observed that during monsoon season in July and September, a large number of agroclimatic zones in the Indo-Gangetic plains up to the NE show decreasing trend $(-0.25$ to -0.07 events/year). On the contrary, from July to September and during pre-monsoon, the number of agroclimatic zones in the central and western parts and also peninsula India show increasing trend (0.05-0.23 events/year). In December, agroclimatic zones in large parts of the country show a decreasing trend ( -0.06 to -0.01 events/year).
Even in Tamil Nadu, where the NE monsoon is usually active, heavy rainfall is found to decrease in January. In general, in the high rainfall zones of NE India, most of the agroclimatic zones show decreasing trends during most months in the year.

One striking feature is that during all monsoon months, the rainy days in several agroclimatic zones in NE India are decreasing, while in a large number of agroclimatic zones in central, western and southern parts, they are increasing (Figure 4). In September, in addition to the states of NE India, as mentioned, a large number of agroclimatic zones in the eastern India also show decreasing trend. In the pre-monsoon season, increasing trends are observed in April in northwest, central and peninsular India, while decreasing trends are observed in March as well as February. In December, several agroclimatic zones in the Indo-Gangetic plains, including the northern states show decreasing trends ( -0.04 to -0.01 days/year). Vijay Kumar et al. ${ }^{9}$, while studying rainfall amount and number of rainy days in river basins of India (19512004), found that six basins showed an increasing trend and one basin showed a significant positive trend. In the present study, trend of rainy days has shown an increase in the western part of India.

According to the Fifth Assessment Report (AR5) of the Intergovernmental Panel on Climate Change (IPCC, 2014), global average temperature has shown a $0.85^{\circ} \mathrm{C}$ increase over the period 1800-2012, and this trend of global warming is predicted to likely increase during the 21 st century. Hence analysis has been carried out to study changes in temperature and rainfall during the past 30year epochs in addition to monthly analysis.

Figure $5 a$ and $b$ shows how the temperature, both maximum and minimum, has changed in the recent past 


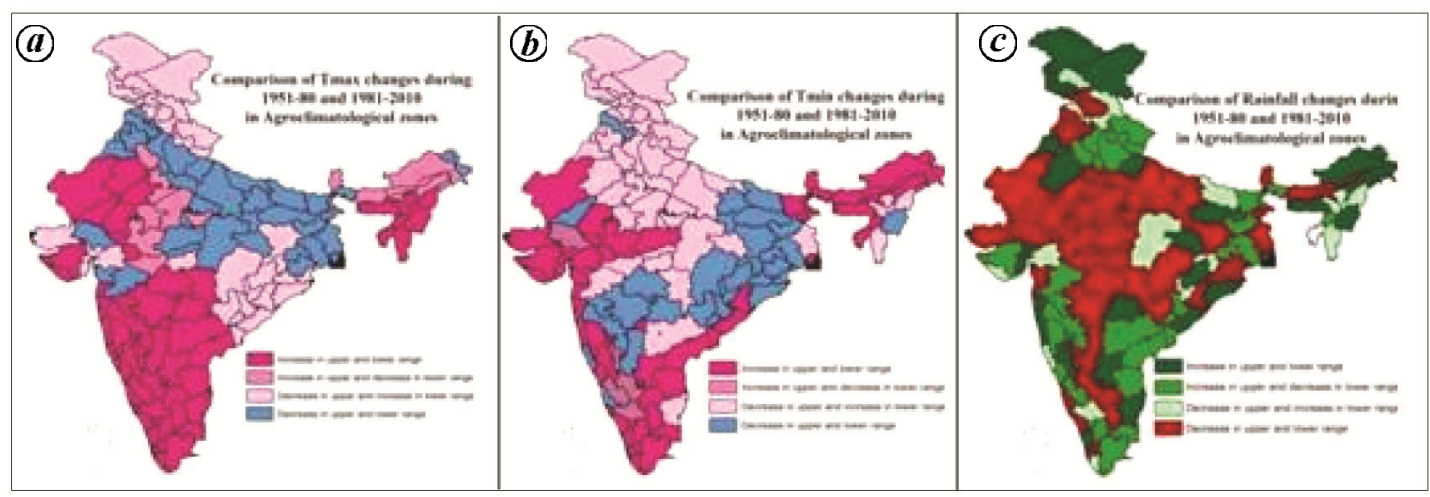

Figure 5. Comparison of $(\boldsymbol{a})$ maximum temperature changes, $(\boldsymbol{b})$ minimum temperature changes and (c) rainfall changes in agroclimatic zones of India.

(1985-2015). Inter-comparison of rainfall and mean temperature (maximum and minimum) has been categorized in four ranges, i.e. increase in the upper and lower range, increase in the upper and decrease in the lower range, decrease in the upper and increase in the lower range, and decrease in the upper and lower range. When both the upper and lower values are positive, it indicates more warming compared to the past, and vice versa, where it is either positive or negative, warming may be either positive or negative depending on the extent of magnitude. In the present study, maximum warming is observed (i.e. increase in upper and lower range) over most of the agroclimatic zones of peninsular India, Rajasthan, some parts of Gujarat and states of the NE like Manipur, Mizoram and Tripura (on an average $0.4^{\circ} \mathrm{C}$ to $0.5^{\circ} \mathrm{C}$ ). Increase in upper range values (on an average $0.23^{\circ} \mathrm{C}$ ) of maximum temperature compared to the previous 30 years has been observed in the states adjacent to central peninsula regions, i.e. some parts of Jharkhand and also in Arunachal Pradesh. Increase in lower range values of maximum temperature $\left(0.6^{\circ} \mathrm{C}\right)$ has been observed in Odisha, Chhattisgarh, Jharkhand and hill areas of the Himalaya. Decrease in lower and upper range values $\left(-0.5^{\circ} \mathrm{C}\right.$ to $0.6^{\circ} \mathrm{C}$ ) is observed in the Indo-Gangetic plains. Increase in lower and upper range values for minimum temperature (on an average $0.22^{\circ} \mathrm{C}-0.43^{\circ} \mathrm{C}$ ) is observed in the southern peninsula, northwest and NE India, and adjoining sub-Himalayan West Bengal. Increase in upper range values is observed (on an average $0.03^{\circ} \mathrm{C}$ ) in interior Karnataka and some parts of Gujarat. Increase in lower range values (on an average $0.4^{\circ} \mathrm{C}$ ) in most parts of North India and Telangana. Decrease in upper and lower range values (on an average $-0.45^{\circ} \mathrm{C}$ to $-0.33^{\circ} \mathrm{C}$ ) is observed in eastern India and parts of central India.

Figure $5 c$ shows a decrease in upper and lower range values of rainfall (on an average $-153 \mathrm{~mm}$ to $-84.1 \mathrm{~mm}$ ) over most of the agroclimatic zones in dry farming tracts and the adjoining agroclimatic zones of Uttar Pradesh, Jharkhand and Sikkim. However, increase in upper and lower range values of rainfall (on an average 103 to $150 \mathrm{~mm}$ ) is observed in most states of the NE, parts of eastern and western India, and the hilly states of the Himalaya.

In India from the period of the Green Revolution, extensive efforts are being made to increase agricultural production/productivity using improved seed quality, better technology, more irrigation facilities, etc. As part of such initiatives, ICAR (1991) has classified the whole country into 127 homogeneous agroclimatic zones taking weather as a major input along with soil and crop information for cultivation of suitable crops in appropriate regions. Weather/climate plays a major role in crop growth. Any change from normal weather adversely affects crop production. It has been established with a fair degree of accuracy that climate is changing over India as a whole and also at the regional level. This may affect the agroclimatic classification, in the country and ultimately crop growth. In view of this, the present study has been undertaken to estimate the rate of change, if any, in two principal parameters, viz. temperature and rainfall along with rainy days and heavy rainfall at the agroclimatic zone level. The major findings are as follows:

- Many agroclimatic zones of NE India are experiencing warming effect as well as decrease in rainfall, heavy rainfall and rainy days at different temporal scales.

- During monsoon, most of states exhibited increasing trends in minimum temperature during the past 31 years.

- Most of the agroclimatic zones in Gujarat exhibited increasing trend in minimum temperature, but decreasing trend was observed in maximum temperature and rainfall along with heavy rainfall and rainy days at various significant levels.

- Increasing trends of mean minimum temperature on different temporal scales were observed in various agroclimatic zones in the northern plains of the country.

- The hilly regions exhibited decreasing trend in rainfall and increasing trend in mean minimum and maximum temperatures. 
- Central and peninsular India exhibited increasing frequency of heavy rainfall events during pre-monsoon and monsoon.

- Study between two episodes (1951-1980 to 19812010) suggests that peninsular India, Gujarat and states of the NE are warming more compared to the northern states (@0.01 ${ }^{\circ} \mathrm{C} /$ year), while the dry farming tracts of the country are experiencing a decreasing trend in the rainfall activity.

In the present study, the observed climate change at various agcroclimatic zones in the northeastern states, Gujarat, hilly areas of the country, and central and peninsular exhibits significant increasing/decreasing trends in weather parameters like temperature, rainfall, heavy rainfall and rainy days. This definitely indicates change in climate from pre-90 to post-90s. Thus, all these changes of climatic parameters would have a definite impact on the classification of agroclimatic zones. Therefore, we must reconsider the classification of agroclimatic zones in India under the scenario of observed climate change in the country.

1. ICAR, agroclimatic zone specific research. In Indian Perspectives under NARP, Indian Council of Agricultural Research, New Delhi, 1991.

2. Kothawale, D. R., Munot, A. A. and Krishna Kumar, K., Surface air temperature variability over India during 1901-2007 and its association with ENSO. Climate Res., 2010, 42, 89-104; doi:10.3354/ cr00857.

3. Srivastava, A. K., Kothawale, D. R. and Rajeevan, M. N., Variability and long-term changes in surface air temperatures over the Indian subcontinent. In Observed Climate Variability and Change over the Indian Region, Springer, Singapore, 22 November 2016, 2017, 1st edn, pp. 17-36.

4. Naidu, C. V., Srinivasa Rao, B. R. and Bhaskar Rao, D. V., Climatic trends and periodicities of annual rainfall over India. Meteorol. Appl., 1999, 6, 395-404; doi:10.1017/S1350482799001358.

5. Chung, C. E. and Ramanathan, V., Weakening of North Indian SST gradients and the monsoon rainfall in India and the Sahel. J. Climate, 2006, 19, 2036-2045.

6. Parthasarathy, B. and Dhar, O. N., Climate fluctuations over Indian region-rainfall: a review. Research Report No. RR-025. Indian Institute of Tropical Meteorology, Pune, 1978, p. 14.

7. Rupa Kumar, K., Pant, G. B., Parthasarathy, B. and Sontakke, N. A., Spatial and sub-seasonal patterns of the long-term trends of Indian summer monsoon rainfall. Int. J. Climatol., 1992, 12, 257-268.

8. Guhathakurta, P. and Rajeevan, M., Trends in rainfall pattern over India. Int. J. Climatol., 2008, 28, 1453-1469.

9. Vijay Kumar, S. and Jain, K., Trends in rainfall amount and number of rainy days in river basins of India (1951-2004). Hydrol. Res., 2011, 42(4), 290-306; doi:10.2166/nh.2011.067.

ACKNOWLEDGEMENTS. We thank Dr S. Khedikar, Smt Gracy John, Smt V. R. Choudhary, Smt Nivedita Tidke, Smt B. S. Kurtkoti, Smt Shweta Mukim and Shri Gaurav Sharma from Agricultural Meteorology Division, India Meteorological Department, for help during data analysis.

Received 6 April 2018; accepted 21 May 2019

doi: $10.18520 / \mathrm{cs} / \mathrm{v} 117 / \mathrm{i} 3 / 480-486$

\section{Soybean methylation analysis during strontium stress using methylation-sensitive amplified polymorphism}

\author{
Qingyuan $\mathrm{He}^{*}$, Zhengpeng Li, Yingjie Shu, \\ Songhua Wang and Shoucheng Huang \\ Life Science College of Anhui Science and Technology University, \\ Fengyang, Auhui 233100, China
}

The effect of strontium stress on the pattern and degree of DNA methylation in soybean seedlings was analysed using the methylation-sensitive amplified polymorphism (MSAP) method. The growth traits were inhibited by $\mathrm{SrCl}_{2}$ treatments. A total of 167 loci were determined and evaluated for DNA methylation after different treatments. The level of cytosine methylation initially decreased and then increased with increasing $\mathrm{Sr}$ concentration. Methylation was lowest after $10 \mathrm{mmol} / \mathrm{l} \mathrm{SrCl}_{2}$ treatment. Strontium stress resulted in a $57.48 \%$ alteration of DNA methylation patterns in $5^{\prime}$-CCGG-3' loci. The pattern variation initially decreased and then increased along with increasing strontium concentration. There was a positive correlation between the total methylation and full methylation induced by strontium stress, and weight and length of shoots and roots in soybean. Overall, the changes in the pattern and degree of methylation may be a key regulatory mechanism for soybean adaptation to strontium.

Keywords: Methylation/demethylation, polymorphism, soybean, strontium stress.

STRONTIUM ( $\mathrm{Sr}$ ) is an essential microelement for the human body that plays an important role in bone formation and vascular endothelial cell proliferation ${ }^{1,2}$. However, a variety of diseases may be caused by elevated strontium levels in drinking water and the food chain. Strontium can be deposited in human bone tissue and remain there for many years. It can cause acute and chronic injury to nerve regulation function and cardiovascular function, and can also cause immune dysfunction ${ }^{3}$. Strontium has been widely used in kinescope, fireworks and radiotherapy, as well as in the pharmaceutical and nuclear industries ${ }^{4}$. Increasing amounts of strontium are being released into the soil, water and environment.

To overcome this problem, there is an effective measure to store strontium into the plant. The method is a clean, cost-effective and feasible technology. Previous studies have indicated that low doses of strontium in the environment promote $\mathrm{CO}_{2}$-fixation capacity of plants, thus accelerating the electron transport of photosystem II complex (PS II), water photolysis and oxygen evolution,

*For correspondence. (e-mail: heqingyuan1@163.com) 